\title{
A Note on Meiros in Phrygia
}

\author{
Stephen MITCHELL*
}

The publication of inscriptions by Eda Akyürek-Şahin and Hüseyin Uzunoğlu from Başara, at the east edge of the Phrygian Highlands, has encouraged me to review a text which has previously been misread, but appears to indicate that the find spot lay within the territory of the Phrygian city of Meiros. The extent and importance of the territory of Meiros in late antiquity have been underestimated.

In MAMA I, W. M. Calder published a sixth century Christian epitaph, recorded at Başaran (Başören, Başara), close to (Hosrev Paşa) Han at the east side of the Phrygian Highlands, as follows: ${ }^{1}$

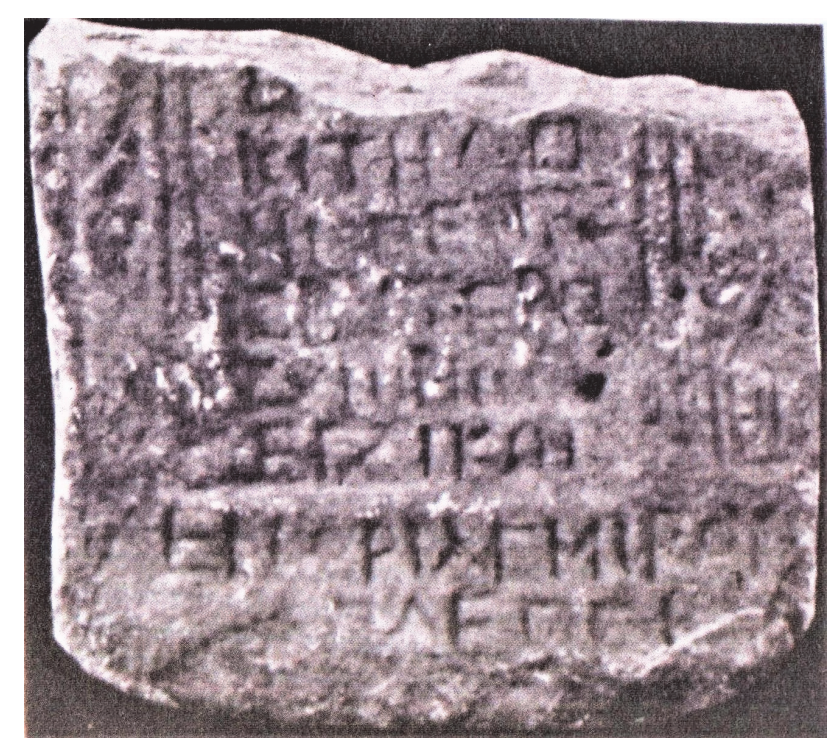

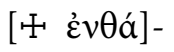

$$
\begin{aligned}
& \delta[\varepsilon \kappa a \tau \alpha ́]-
\end{aligned}
$$

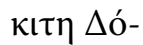

$$
\begin{aligned}
& 4 \\
& \mu \nu \circ \varsigma \pi \rho \varepsilon-
\end{aligned}
$$

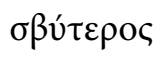

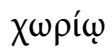

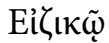

$$
\begin{aligned}
& 8 \\
& \text { Ėvopías Mípov }
\end{aligned}
$$

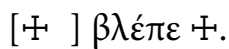

Louis Robert wrote a short article based on the word $\beta \lambda \varepsilon \dot{\pi} \varepsilon$ in the last line, and referred to this inscription on several occasions as an example of the formula that invited the reader to contemplate the finality of death. ${ }^{2}$ However, this discussion was misplaced. The photo published by Calder shows that this text should be emended. The stone-cutter of this simple Christian epitaph mostly used square forms for omikron and sigma as well as epsilon. The letter before lambda is the

* Prof. Dr. Stephen Mitchell, Berlin, Germany (mitchank@gmail.com; https://orcid.org/0000-00019623-0983).

${ }^{1}$ MAMA I 403; now in the Inscriptiones Christianae Graecae repository, ICG 1704 (http://repository. edition-topoi.org/collection/ICG/object/1704), with further bibliography.

${ }^{2}$ Robert 1944, 53-56, summarised in Bull. Ép. 1943, 70: 'В $\lambda \varepsilon \dot{\pi} \varepsilon \varepsilon$ qui se trouve dans une épitaphe chrétienne de Phrygie (MAMA I, 403). Cette formule entre dans une série d'expressions, païennes ou chrétiennes, plus ou moins développées, où l'on rappelle au lecteur des épitaphes le terme de leur vie (cf. $\tau a \tilde{\tau} \tau \alpha$,

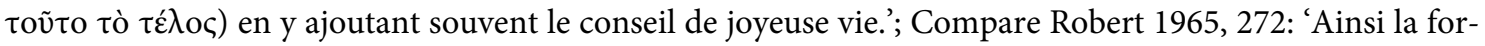

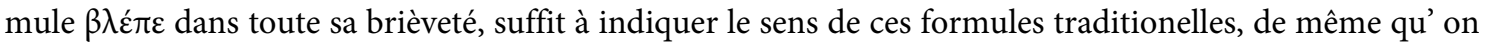

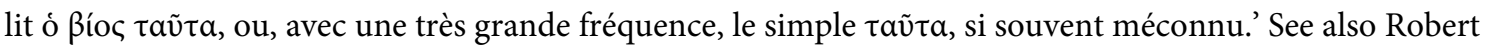
1980,267 n. 52. 
top of a square omikron, not a beta, the penultimate letter has the same form, and the last letter is

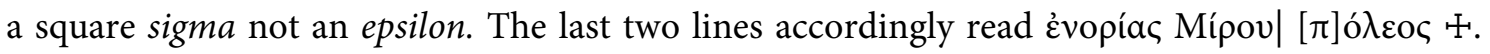
Exactly this formula appears on the gravestone on the island of Proconnesus of an emigrant from

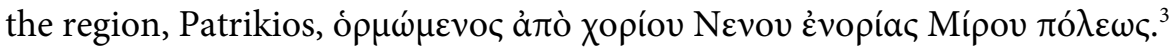

Meiros is named as a katoikia on a base set up to honour Cornelia Salonina Augusta in the mid-

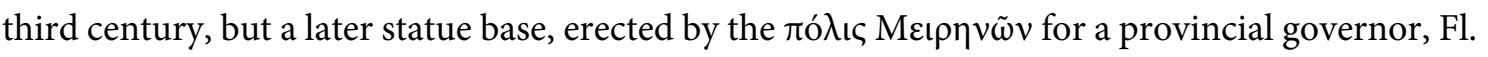
Optimus, shows that it subsequently gained the status of a polis. ${ }^{4}$

$$
\begin{aligned}
& \text { Aya日ñ Túxn }
\end{aligned}
$$

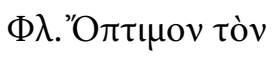

$$
\begin{aligned}
& \delta\llcorner\alpha \sigma \eta \mu . \dot{\eta} \gamma \varepsilon \dot{\mu} \mu \mathrm{ov \alpha}
\end{aligned}
$$

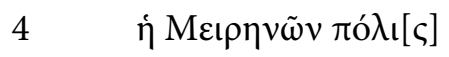

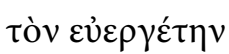

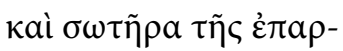

$$
\begin{aligned}
& \text { xíov } \\
& \Delta \mathrm{IKI} \ldots \text {. II } \Delta \Omega \text { IПEPI }
\end{aligned}
$$

Anderson, the discoverer of these inscriptions, identified the ancient settlement with a largely denuded and characterless ruin field at Geriz Malatyası (also called Malatça, now Demirözü). Most of the building stone had been taken to Kütahya around 1890. and the despoliation of the site was aggravated by the building of the railway between Kütahya and Afyon. ${ }^{5}$

The city, in the valley of Çandırar Deresi, was not only located on the railway line, but also stood at the intersection of the Roman roads running SW/NE between Soa and Nacolea, and NE/SW between Cotiaeum and Philomelium and benefited from this geographical advantage. ${ }^{6}$ It was one of several settlements of central Anatolia in late antiquity which grew in status and importance

\footnotetext{
${ }^{3}$ Gedeon 1895, pl. III. 21, cited by Hasluck 1910, 290 n. 2 and Mitchell 1975, 275-276.

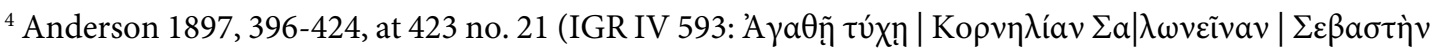

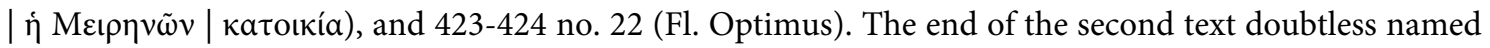
the official who took charge of putting up the statue. A deputation from a community called Meĩpo

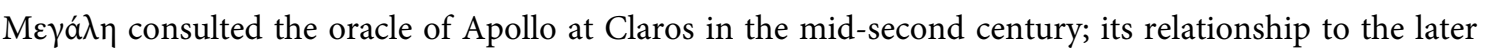
katoikia and polis at Malatça is uncertain and the problem needs further investigation; see J. and L. Robert, Bull. Ép. 1972, 461.

${ }^{5}$ Anderson 1897, 423: 'The ruins which run out from the base of an oval-shaped hill, the acropolis no doubt of an old city, are mostly characterless, but we were told that formerly there were many marbles there, most of which have been carried off by natives of the district to Kutaya - twenty-five they say were taken away by mosque builders from that city six or seven years ago - while the German railway (which passes through the narrow plain) had destroyed great numbers "written and unwritten"'. Inscriptions from Malatça were collected and published by Haspels 1971, 330 nos. 86-90.

${ }^{6}$ It is at the intersection of routes D5 and A2 in the reconstruction of Belke and Mersisch in TIB 7, 140, but not mentioned in their road descriptions, and at the intersection of routes D24 and D9 as suggested by French 2016. French marked the location of Meiros on p. 133 but omits the name. His detailed maps show the ancient cities and the road lines overlaid on the Turkish 1:500,000 survey (see p. 15, 61, and 141 for the Eskişehir sheet).
} 
between the third and fourth centuries, and can be compared with Soa (Altıntaş) in the Upper Tembris Valley, ${ }^{7}$ Tymandos in southern Phrygia west of Hoyran Lake, ${ }^{8}$ and Orcistus in eastern Phrygia, which was dependent on Nacolea up to the time of its famous petition to Constantine. ${ }^{9}$ These developments can be linked to important changes in the settlement pattern of Phrygia in late antiquity. Cities that had previously been dominant, such as Aezani, lost importance and new villages emerged in previously thinly settled countryside as the rural population increased. ${ }^{10}$ The civic political hierarchy was influenced by these changing demographic conditions. Meiros itself subsequently appears in the Synekdemos of Hierokles, stood on the boundary of the themata Anatolikon and Opsikion in the ninth century, and existed as a bishopric until the twelfth century. ${ }^{11}$

Meiros in late antiquity evidently eclipsed the old Phrygian centre of Metropolis, which had lost its civic status long before this period. ${ }^{12}$ The text published by Calder states explicitly that the village of Eizikos lay on the territory of the city of Meiros, and there is no reason to question the obvious interpretation that Eizikos was the spot where the priest Domnus was buried. This was fifty kilometres east of Meiros as the crow flies. For comparison, we may note that the settlement of Orcistus was a similar distance from Nacolea. In the sixth century the large territory of Meiros stretched eastwards beyond the imperial estates of the Kümbet valley and around Malos, ${ }^{13}$ and covered most of the Phrygian highlands. It shared borders with Amorium to the east, Docimium to the south and Nacolea to the north.

\section{Abbreviations}

Bull. Ép. Bulletin épigraphique (published annually in Revue des études grecques).

CIL Corpus inscriptionum Latinarum.

ICG Inscriptiones Christianae Graecae (http://repository.edition-topoi.org/collection/ ICG).

IGR Inscriptiones Graecae ad Res Romanas Pertinentes.

ILS Inscriptiones Latinae Selectae

JHS Journal of Hellenic Studies.

\footnotetext{
${ }^{7}$ For Soa see IGR IV 605 and MAMA X xx n. 15. The Aragua petition of AD 244-7 indicates that the Soenoi had previously been dependent on Appia, MAMA X 114 line 8.

${ }^{8}$ Bru et al. 2009, 187-207.

${ }^{9}$ CIL III, 352; MAMA VII, 305 (ICG 1292).

${ }^{10}$ Niewöhner 2007.

${ }^{11}$ References in TIB 7, 337-8.

${ }^{12}$ See TIB 7, 340-1 s.v. Metropolis, suggesting that this should be identified with the ruins at Oineş, ESE of Kümbet, but the old city name, still recorded in Hierokles, Synekdemos 677.12, seems rather to match the cult centre at Yazılıkaya itself. For Kümbet, see the inscriptions for Epinikos praefectus praetorio Orientis c. AD 475 and his wife by an unnamed polis, published by Mommsen 1897; Haspels 1971, 307 nos. 289 (ILS 8845 a and b; ICG 1652 and 1653). The polis was probably Meiros.

${ }^{13}$ For Malos, see TIB 7, 334-5.
} 
MAMA Monumenta Asiae Minoris Antiqua

I. Ed. W. M. Calder (Manchester 1928).

VII. Ed. W. M. Calder (Manchester 1955).

X. Ed. B. M. Levick, S. Mitchell, J. Potter and M. Waelkens (London 1993).

TIB $7 \quad$ K. Belke - N. Mersich, Tabula Imperii Byzantini 7. Phrygien und Pisidien (Vienna 1990).

\section{Bibliography}

Anderson 1897

J. G. C. Anderson, A summer in Phrygia I, JHS 17, 1897, 396424.

Bru et al. 2009 H. Bru - G. Labarre - M. Özsait, La constitution civique de Tymandos, Anatolia Antiqua 17, 2009, 187-207.

French 2016

D. H. French, Roman Roads and Milestones of Asia Minor III. Fasc. 9. An Album of Maps, 2016 (free download at https:// biaa.ac.uk).

Gedeon 1895

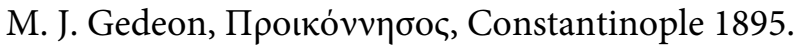

Hasluck 1910

F. W. Hasluck, Cyzicus, Cambridge 1910.

Haspels 1971

C. H. E. Haspels, The Highlands of Phrygia: Sites and Monuments, 2 vol., Princeton-New Jersey 1971.

Mitchell 1975

S. Mitchell, Review of Haspels, Highlands of Phrygia, JHS 95, 1975, 275-276.

Mommsen 1897

Niewöhner 2007

Robert 1944

Robert 1965

T. Mommsen, Epinikos, Hermes 32, 1897, 660-663.

P. Niewöhner, Aizanoi, Dokimion und Anatolien. Stadt und Land, Siedlung und Steinmetzwesen vom späteren 4. bis ins 6 . Jht. n. Chr., Wiesbaden 2007.

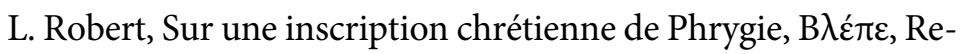
vue de philologie 18, 1944, 53-56 (see Opera Minora Selecta III, 1419-1422).

L. Robert, Hellenica. Recueil d'épigraphie, de numismatique et d'antiquités grecques, vol. XIII, Paris 1965.

Robert 1980

L. Robert, À travers l'Asie Mineure. Poètes et prosateurs, monnaies grecques, voyageurs et géographie, Paris 1980. 


\section{Phrygia'daki Meiros Hakkında Bir Not \\ Özet}

Phrygia Bölgesi’nde Başara'da bulunan 6. yy’a ait bir mezar yazıtının (MAMA I 403) son sözcüğü W. M. Calder tarafından ilk yayınında B $\lambda \dot{\varepsilon} \pi \varepsilon$ olarak okunmuştur. Bu okuma Louis Robert'i yanlış bir yoruma yönlendirmiştir. Doğru okuma $[\pi]$ ó $\ell \varepsilon o \varsigma$ sözcügüüür. Mezar yazıtı Phrygia kenti Meiros’un egemenlik alanındaki Eizikos Köyü’ndeki bir mezar yapısına işret etmektedir. Meiros nemli bir yol kavşağında bulunnaktaydı ve geç antik çağda önem kazanmıştı. Kentin egemenlik alanı genel olarak bilinenden daha fazlaydı ve Phrygia Dağlık alanının büyük bir kısmını kaplamaktaydı.

Anahtar Sözcükler: kent teritoryumu, Hiristiyan mezar yazıtı, Phrygia.

\section{A Note on Meiros in Phrygia}

Abstract

The last word of a sixth-century epitaph from Başara in Phrygia (MAMA I 403) was misread as $B \lambda \dot{\varepsilon} \pi \varepsilon$ in the first publication by W. M. Calder, leading to misplaced commentary on this term by Louis Robert. The correct reading is $[\pi]$ ó $\lambda \varepsilon o c$. The epitaph marks a burial in the village of Eizikos on the territory of the Phrygian city of Meiros. Meiros stood at an important road intersection and gained importance in late antiquity. Its territory was larger than is commonly assumed and covered most of the Phrygian Highlands.

Keywords: city territory, Christian epitaph, Phrygia. 